\title{
COMPARATIVE ANALYSIS OF THE PHYSICAL DEVELOPMENT AND SPORTS PREPAREDNESS OF “BEROE” BASKETBALL CLUB (BC) BASKETBALL „CADETS” 16 TEAM
}

\author{
Yavor Asparuhov, Mariana Borukova
}

National Sports Academy "Vassil Levski", Sofia, Bulgaria

\begin{abstract}
Modern basketball game is characterized by higher general and specific endurance, which requires by the competitors important increase of their physical abilities. That requires from the sports expert to skillfully plan and manage the process of the sports preparation while the training impacts should be strictly controlled because in the organism of the coming athletes occur a range of morphological and functional changes which should be recorded and carefully analyzed. The purpose of the present study is to make a comparative analysis and evaluation of the physical development and the specific workability of the basketball team of "Beroe". The present study was made during the period from October 2018 to May 2019. Subject of the study are the physical development and the specific workability of 16 years old basketball cadet players. Object of the study are the basic signs of the physical, technical and tactical preparedness in basketball. All competitors of the team have been tested by 20 indicators, bearing information about the basic signs of the physical development and the specific basketball workability. Results: For both studies, the group is homogeneous and relatively homogeneous in relation to the signs under observation. Following the application of the specific methodology, it was established that statistically important difference is observed for six of the signs under observation. It can be generalized that the competitors from the team of "Beroe" have considerably improved their speed endurance, the speed of moving along the ground with and without a ball, as well as the specific basketball movement while standing in defense.
\end{abstract}

Key words: coming up athletes, basketball, training process

\section{INTRODUCTION}

Modern basketball is characterized by increased general and specific endurance requiring from the basketball players considerable increasing of their physical abilities. Nevertheless, the coming fatigue they should be able to manifest their technical and tactical skills during each part of the competition. That requires from the sports experts to plan and manage skillfully the process of the sports preparation because in the organism of the coming up athletes occur a range of morphological and functional changes, which should be recorded and carefully analyzed. The complex development of the motive qualities set up the question about the evaluation and control on the specific functional preparation of the athletes. Up to that purpose, many researchers are developing specific basketball tests and indicators (Gyosheva,, et al, 1990; Dasheva, 1991; Zheliazkov, 1978; Petrov, 1998; Tsarov, 2008; Tsarova, Borukova, 2012; Tsarova, 2013).

Scientific team composed of R.Tsarova, Kr. Tsarov and M. Borukova held studies with 125 basketball players (15-16 year of age) listed in the national team of Bulgaria during the period 2009-2016 applying the same test battery. They draw up a factor structure of eight factors which as a whole explains the rather high percentage of the starting dispersion of the phenomenon under study $-73,02 \%$ and establish that the so-called morphological factor disclosing the high importance predominantly of the linear dimensions of the body is the most important for the general preparedness for that age. The indicators related to the physical preparedness of the competitors identify the forth factor as the so-called "basketball athletism" (Borukova, Kuleva, Tsarova, 2017).

Basketball coaches in Bulgaria, working with coming up players apply various methodologies. The present study is based on a specific methodology we have applied for one sport competitive year to the young cadet basketball players of "Beroe" BC in the town of Stara Zagora; we wanted to establish its impact on the young players. The inquiry we have initiated with basketball coaches in relation to the planning of the year preparation of young players, 
Yavor Asparuhov and Mariana. Borukova establish that the level of the speed-force preparation of the young competitors is average or low (Borukova. Asparuhov, 2019).

It is known that because of the representativeness of the extracts, the decisions taken during the checkup of the statistical hypothesis are of probability character (Gigova, 1999). The acceptance or rejection of the zero hypothesis is made at a certain level of certainty while at the same time admitted is the possibility to make statistical mistake. The analysis of the facts, our personal experience and observations give us the reason to formulate the following working hypothesis: we admit that the present study shall allow us to establish whether the priority development of the technical skills and the strength abilities of 15-16-year-old basketball players shall increase the level of their specific workability.

Purpose of the present study is to establish the level of the physical development and the specific workability of the basketball cadets 16 team affiliated to "Beroe" BC at the city of Stara Zagora.

\section{METHODOLOGY}

The present study was made during the period October 2018 till May 2019.

Subject of the study are the physical development and the specific workability of 16-year-old basketball players.

Object of the study are the basic signs of the physical, technical and tactical preparation in basketball.

Fourteen basketball players, born in 2002-2003 from "Beroe" BC, participating in the National championship of the BBF, have been studied.

For the execution of the purpose set and the tasks of the study, applied are the following methods of research:
1. Review study and theoretical analysis of specific literature as well as documental sources - for establishing the status of the issue under study. On that base, selected are sufficient number of tests and indicators, answering the requirements for reliability, authenticity, objectiveness and standard, listed in the test battery of the study.

2. Anthropometry - for disclosing the status of the basic anthropometric signs by collecting information about 3 indicators (see table 1). The measurements are made by standard devices and according to standard methodology (Slanchev, 1998).

3. Sport-pedagogical test - for establishing the level of the specific physical preparedness and the specific technical and tactical skills of the basketball players under study. Tested are all competitors from the team according to 17 indicators, presented in table 1 (from No. 5 to No. 20) for the needs of the study at the beginning and at the end of the sport competitive year (2018-2019).

Depending on the information they bear, the indicators are distributed in two groups as follows:

$\checkmark$ about the physical preparedness - 7 indicators (from 5 th to $11^{\text {th }}$ );

$\checkmark$ about the specific technical and tactical preparedness -8 indicators (from $12^{\text {th }}$ to $20^{\text {th }}$ ).

The results of the study were subjected to mathematical and statistical processing by:

1. Variation analysis - for defining the average levels and the variety of the indicators under study for each of the totalities under study.

2. Index method - Body Mass Index - BMI, recommended by the World health organization for establishing the degree of the body's weight put on.

3. Comparative $t$ - criterion of Student for dependable extracts - for checking the reliability of the differences between the average levels of the signs under study for "Beroe" BC team for both realized studies.

Applied is the following formula for dependable extracts:

$$
t \operatorname{emp}=\frac{\left[\mathrm{d}^{-}\right]}{\frac{\sum \mathrm{d}^{2}-n \mathrm{~d}^{2}}{\mathrm{n}^{2}-\mathrm{n}}}
$$

Where: $d$ - average value of $d, n$-volume of the extract, $\Sigma d^{2}$ - the sum of $d$ squared.

The critical value of $t$-criterion at high statistical needs of the sports practice (Brogli, et al 1992). reliability ( $\mathrm{Pt} \geq 95 \%$ ), is $t_{a}=2,16$ That satisfies the 


\section{Analysis}

For the purpose and the tasks of the study, the initial data from both tests were processed by the help of variation analysis (Table 1 ).

The results show that for both tests the values of the indicators have normal or close to the normal distribution.

For the needs of the research, we have compared the average values of the results from the executed studies. Analyzing Table 1 we have established that from 20 indicators under study, 16 show improvement of the results.

The comparative analysis of the physical development and the physical preparedness signs is presented on Table 1 .

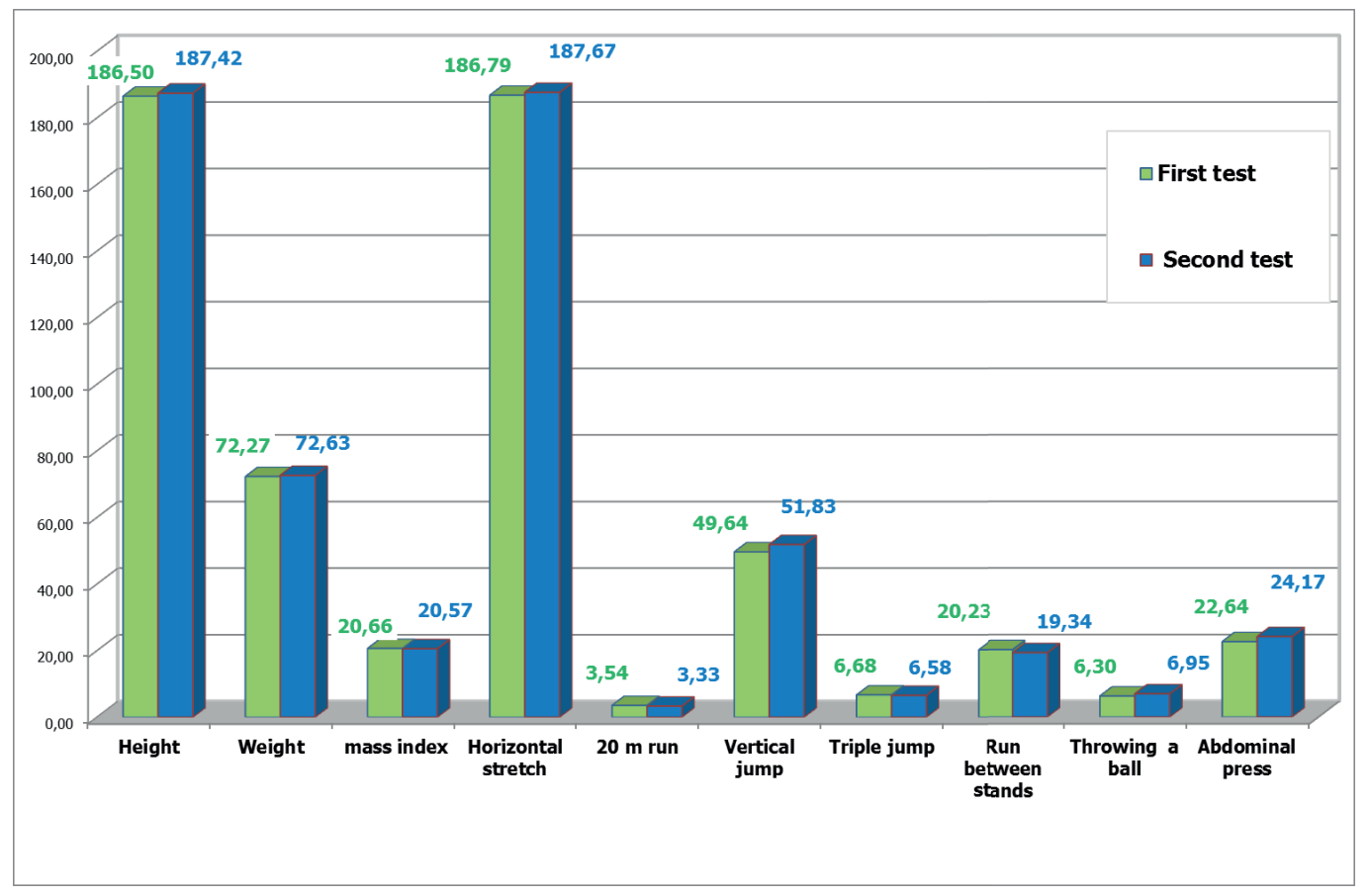

Figure 1. Comparative analysis of the average physical development and physical preparedness indicators

Observed are higher average values for all indica- No. 7 Triple jump the average values are lower in tors following the second study except for indicator comparison with the first study.

Table 1. Comparative analysis of the average and dispersal indicators of the signs under study

\begin{tabular}{|c|c|c|c|c|c|c|c|c|c|c|c|}
\hline \multicolumn{7}{|c|}{ First test } & \multicolumn{5}{|c|}{ Second test } \\
\hline & Indicator & $\mathbf{X}$ & $\mathbf{S}$ & As & $\mathbf{E x}$ & $\mathbf{V}$ & $\mathbf{X}$ & $\mathbf{S}$ & As & $\mathbf{E x}$ & $\mathbf{V}$ \\
\hline 1. & Height & 186,50 & 0,099 & $-0,502$ & $-0,187$ & 5,29 & 187,42 & 9,991 & $-0,416$ & $-0,234$ & 5,33 \\
\hline 2. & Weight & 72,27 & 12,113 & $-0,339$ & $-0,499$ & 16,76 & 72,63 & 10,508 & $-0,365$ & 0,72 & 14,47 \\
\hline 3. & Body mass index & 20,66 & 2,235 & 0,445 & $-0,628$ & 10,82 & 20,57 & 1,435 & $-0,303$ & $-1,365$ & 6,98 \\
\hline 4. & Horizontal stretch & 187,00 & 0,119 & $-0,418$ & $-0,033$ & 6,39 & 187,67 & 12,161 & $-0,504$ & 0,162 & 6,48 \\
\hline 5. & $20 \mathrm{~m}$ run & 3,54 & 0,221 & $-0,973$ & 0,659 & 6,25 & 3,33 & 0,129 & $-0,561$ & $-0,512$ & 3,88 \\
\hline 6. & Vertical jump & 49,64 & & & 0,806 & & & 6,191 & 0,769 & 1,482 & 11,94 \\
\hline 7. & Triple jump & 6,68 & 0,558 & 0,689 & $-0,198$ & 8,35 & 6,58 & 0,500 & 0,507 & $-1,426$ & 7,60 \\
\hline 8. & Run between stands & 20,23 & 0,773 & $-0,228$ & 1,578 & 3,82 & 19,34 & 0,615 & $-1,045$ & 1,693 & 3,18 \\
\hline 9. & $\begin{array}{l}\text { Throwing compact } \\
\text { ball - forward }\end{array}$ & 6,30 & 0,832 & $-0,029$ & $-1,237$ & 13,22 & 6,95 & 0,927 & $-0,149$ & $-0,674$ & 13,34 \\
\hline 10. & Abdom. presses & 22,64 & 2,649 & $-0,418$ & 0,144 & 11,70 & 24,17 & 2,918 & 0,33 & $-1,729$ & 12,07 \\
\hline 11. & $252 \mathrm{~m}$ "Shuttle" run & 72,01 & 1,103 & 0,936 & 1,087 & 4,23 & 74,75 & 2,504 & 1,223 & 1,593 & 3,35 \\
\hline 12. & Dribble b/n stands & 21,46 & 1,132 & $-0,328$ & 1,37 & 5,27 & 19,91 & 0,650 & $-0,239$ & $-0,861$ & 3,26 \\
\hline
\end{tabular}




\begin{tabular}{|c|l|c|c|c|c|c|c|c|c|c|c|}
\hline 13. & $\begin{array}{l}\text { Leading the ball } \\
\text { index }\end{array}$ & 1,24 & 0,945 & 0,484 & 0,509 & 76,52 & 0,57 & 0,420 & 0,837 & $-0,404$ & 73,24 \\
\hline 14. & Moving in defense & 9,44 & 2,147 & $-3,463$ & 12,587 & 24,39 & 8,90 & 0,308 & $-0,099$ & $-0,81$ & 3,47 \\
\hline 15. & Loops by dribble & 61,72 & 2,848 & $-0,205$ & $-0,541$ & 18,46 & 73,67 & 11,240 & 0,43 & $-0,287$ & 15,26 \\
\hline 16. & Shot on the run - pcs & 5,21 & 0,699 & $-0,321$ & $-0,633$ & 13,41 & 5,67 & 0,492 & $-0,812$ & $-1,65$ & 8,69 \\
\hline 17. & Shot on the run - t & 31,66 & 1,592 & $-0,198$ & $-0,443$ & 5,03 & 31,15 & 1,169 & 0,734 & $-0,436$ & 3,75 \\
\hline 18. & $\begin{array}{l}\text { Shot on the run - } \\
\text { coefficient }\end{array}$ & 6,21 & 1,136 & 0,56 & $-0,258$ & 18,29 & 5,55 & 0,632 & 0,758 & $-1,266$ & 11,40 \\
\hline 19. & Shot from position & 13,93 & 0,715 & 1,280 & 0,080 & 19,19 & 13,50 & 4,890 & 0,28 & $-1,161$ & 36,22 \\
\hline 20. & Free throws & 13,79 & 1,626 & $-0,225$ & $-1,243$ & 11,79 & 13,17 & 3,380 & 0,472 & 0,045 & 25,67 \\
\hline
\end{tabular}

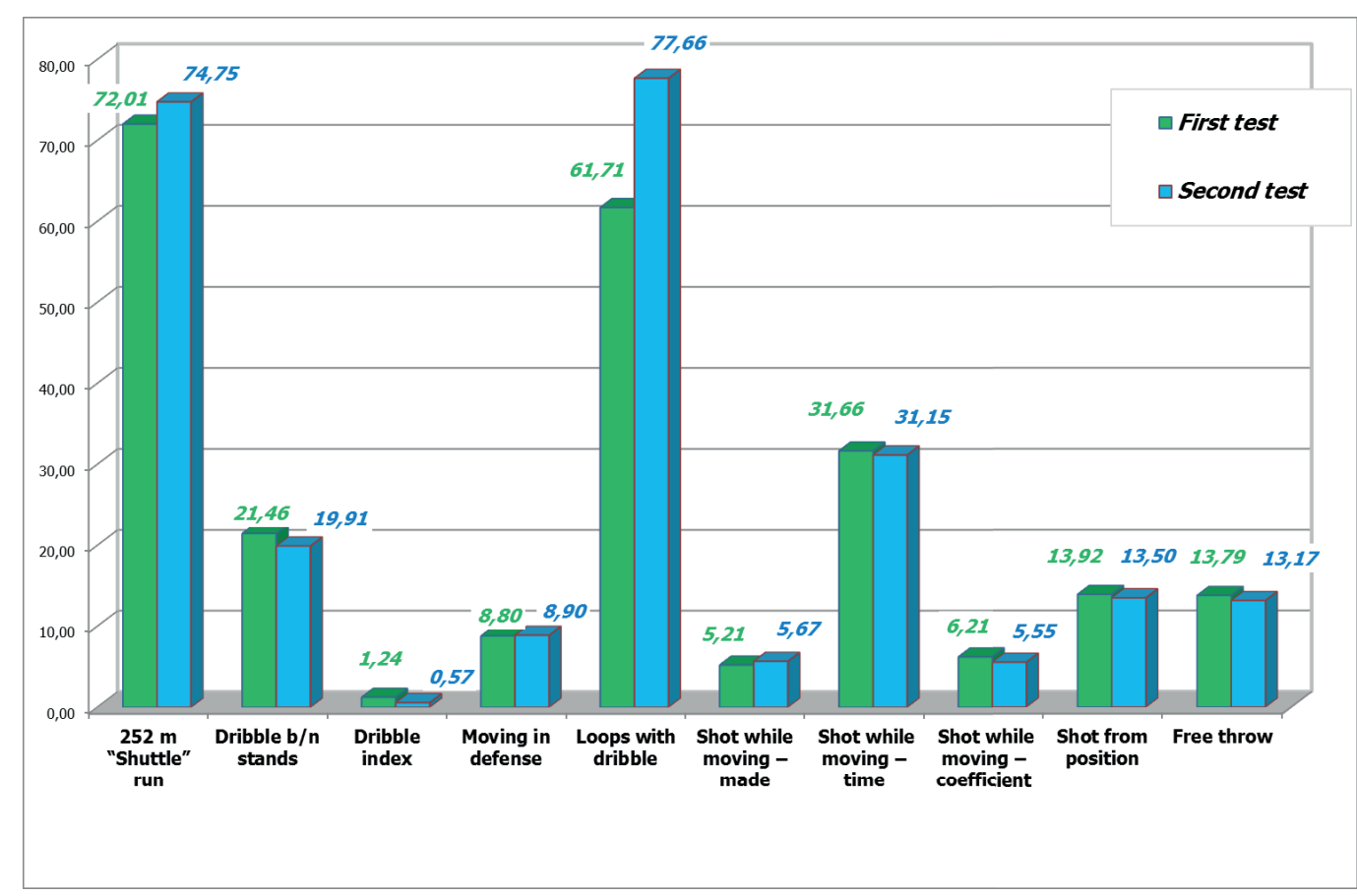

Figure 2. Comparative analysis of the average mechanical and tactical preparedness indicators

Figure 2 shows that for No. 11 " $252 \mathrm{~m}$ "Shuttle" the average values are weaker in comparison with the first research. We have anyway to note that there are two indicators more for which, after the second research, the values of the average are lower than those of the first research are. These are the signs related to the realization skills of the players: indicators No. 19 and No. 20 („Shot from position“ $-\mathrm{X}_{1}=13,93$ and $\mathrm{X}_{2}=13,50$ and „Execution of free throws" - $X_{1}=13,79$ and $X_{2}=13,17$ ), while for indicator No. 20 according to the variation coefficient, the group from being strongly homogeneous at the beginning, becomes relatively homogeneous after the second research. That is not a good sign and means that the young basketball players have heterogeneous skills for realizing shots from the penalty line.

For us it will be important to comprehend whether for the signs studied by us there exist statistically important differences between the average values for both researches. For proving the importance of the differences between the average levels for both researches, applied was a comparative analysis by the t-criterion of Students for dependable extracts. The importance of the differences is presented on Figure 3. 


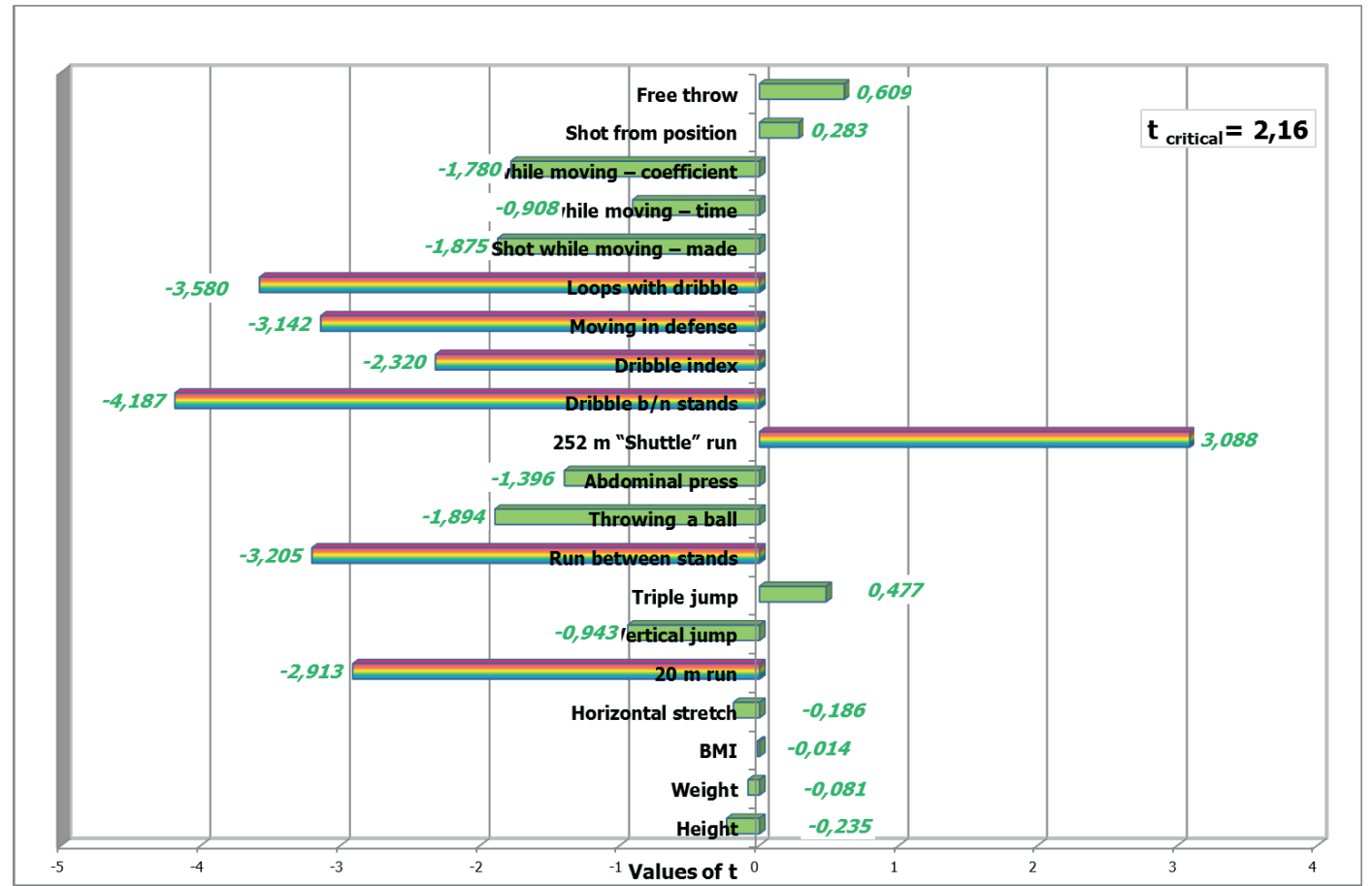

Figure 3. Importance of the values between the average levels of the motive activity signs under study

When analyzing Figure 3, it is evident that from the right side of the figure are the four indicators for which the average values are weaker after the second research. Interesting is to note that for the " $252 \mathrm{~m}$ shuttle" indicator, the empiric value of $t$ is higher than the calculated critical value $\left(t_{\text {crirti- }}\right.$ $\mathrm{cal}=2,16$ ), while such a thing is not observed for the other three indicators. That means that the young basketball players have run the distance much quicker during the first research.

In the left side of the figure presented are the signs for which the average values are better after the second research; but higher empiric values are observed for six of them only. These are $t_{5}=2,91$, $\mathrm{t}_{8}=3,21, \mathrm{t}_{12}=4,19, \mathrm{t}_{13}=2,32, \mathrm{t}_{14}=3,14$ and $\mathrm{t}_{15}=3,5$, which gives us the reason with high guarantee probability ( $\mathrm{Pt} \geq 95 \%$ ) to accept as true the alternative hypothesis according to which the differences between both researches for these indicators are statistically important.

\section{CONCLUSION}

The following conclusions can be made according to the results and analysis of the researches made:

1 . The variation coefficient of the indicators under study for the young basketball players shows that the totality under study is homogeneous and relatively homogeneous in relation to more of the physical development and ability signs under study.

2. The comparative analysis applied gives us the reason to state that the results from the second research are better for 16 of the indicators under study.

3. Observed are statistically important differences for six of the studied signs only. F The difference for the rest 10 signs can be explained by occasional reasons.

\section{DISCUSSION}

„Beroe” BC cadets' 16 team has been working for a period of one sports competitive year according to specific methodology, developed by their coach Yavor Asparuhov which has been directed towards priority development of the technical skills and strength abilities of the competitors. The development of the strength quality shows clearly expressive dependence while some studies show that between the age of 11-14 strength training has similar effect both for the boys and girls. During the age of 15-16 observed is an increase of the girls' strength in comparison with the boys nevertheless the application of one and the same training method. Established is that sex differences are more strongly expressed in the strength of the limbs' muscles and considerably less in the strength of the body's muscles (Borukova, 2018). Following the application of the methodology, it was established that statistically important difference is observed for several of 
the signs under study related mostly to the level of the physical preparedness of the players where excellent technical skills are required too. "Beroe" BC team has considerably improved their speed abilities, the speed of moving along the terrain with and without a ball, the specific basketball movement in defense posture and the skill of manipulating the ball while standing at one place.

\section{CONCLUSION}

For increasing the effectiveness of the training process, it is particularly important to reckon the connection of the basketball player's physical and technical preparation (Borukova, Asparuhov, 2019).

It can be generalized that in view of the competitors' age, the accents of the work in the future school and training process should be directed towards increasing and improving the level of the physical, technical and tactical preparedness signs, as the specific basketball exercises should be executed at higher speed, more exercises should be applied like special speed of moving along the terrain with and without a ball, more work to be done with the lower and upper limbs. The coaches should hold more specific training sessions for perfecting the basic technical basketball methods as well as of the realization skills of the players. It is necessary to present the information of the researches to the coaches with the view of the optimization of the school and training process.

\section{REFERENCES}

Borukova, M. (2011). Izsledvane varhu nivoto na podgotvenost na uchenizite, kandidatstvashti $\mathrm{v}$ sportnite uchilishta s profil basketbol, Sport@Nauka, (Izvanreden broi 2), pp. 89-97. // Борукова, М. (2011). Изследване върху нивото на подготвеност на учениците, кандидатстващи в спортните училища с профил баскетбол, Спорт \& Наука, (Изв. брой 2.) стр. 89-97. Borukova, M. (2018). Control na sportnata podgotovaka pri 13014 godishni basketbolistki. Sofia, Bolid ins. // Борукова, М., (2018). Контрол на спортната подготовка при 13-14 годишни баскетболистки. София, Болид-инс

Borukova, M., Asparuhov, Y. (2019). Prouchvane mnenieto na treniorite po otnochenie planiraneto na godishnata sportna podgotovka na mladi igrachi, Pedagogicheski almanah, tom 27 / Broi 1, Veliko Tarnovo. // Борукова, М., Аспарухов, Я. (2019). Проучване мнението на треньорите по баскетбол по отношение планирането на годишната спортна подготовка на млади играчи, Педагогически алманах, том 27 / Брой 1, Велико Търново.

Gigova, V. (2002). Statisticheska obrabotka I amaliz na danni, Sofia, NSA-IPB. // Гигова, B., (2002). Статистическа обработка и анализ на данни, София, НСА - ИПБ.

Giocheva, K., Tzarova, R., Tzarov, Kr. (1990). Sisrema za kojrol, otzenka I optimtzirane na sportnata podgotovka na momicheta I momcheta - 13-15 godini. Sofia, ETZNPKFKS-IPB, pp.6. // Гьошева, К., Църов, Кр., Църова, Р. (1990). Система за контрол, оценка и оптимизиране на спортната подготовка на момичета $u$ момчета 13-15 години. София, ЕЦНПКФКС - ИПБ, стр.6.

Dasheva, D. (1991). Stres I stresovi vazdeistvija v podgotovkata na basketbolisti, Dis. Trud, VIF, Sofia. // Дашева, Д. (1991). Стрес и стресови въздействия в подготовката на баскетболисти, Дис. Труд. ВИФ. София.

Jeljazkov, Tz. (1978). Metodoligichni osnovi na upravlenieto I optimiziraneto na sportnata podgotovka pri visokokvalifitzirani basketbolisti. Dis. Trud-dpn, Sofia, VIF. // Желязков, Ц. (1978). Методологични основи на управлението и оптимизирането на спортната подготовка при висококвалифицирани баскетболисти. Дисерт. труд - дпн, София, ВИФ.

Petrov, L. (1998). Basketbol, VTU, Veliko Tarnovo. // Петров, Л. (1998). Баскетбол, ВТУ, В. Търново.

Slanchev, P. (1992). Sportna medicina: Uchebnik za student ot NSA. Sofia, Medicina I fizkultura. // Слънчев, П. (1992). Спортна медицина: Учебник за студенти от НСА, София, Медицина и физкултура.

Tzarov, Kr. (2008). Podborat v basketbola, Sofia, NSA pres.//ъров, Кр. (2008). Подборът в баскетбола. София, НСА Прес.

Tzarov, Kr. (2012). Sastezatelnata efektivnost v basketbola, Sofia, Bolid-ins. // Църов, Кр. (2012). Състезателната ефективност в баскетбола. София,Болид инс.

Tzarova, R. (2013). Problemi na kontrola v basketbola, Sofia, Bolid-ins. // Църова, Р. (2013). Проблеми на контрола в баскетбола, София, Болид инс.

Bompa, T. (2002). Periodization: Theory and methodology of training, Editura Ex. Ponto, Bucharest, pp. 123-134 Borukova, M. (2017), Management and control of sports preparation of 14-15-year-old female basketball players, Journal of Applied Sports Sciences 02/2017, Sofia, pp. 19-30

Borukova, M., Kuleva, M., Tsarova, A. (2017). „Factor structure and basic factors of the sports preparedness of 15-16 years old national basketball competitors", Book from the International Scientific Congress "Applied Sciences in Sport",NSA Press,. pp.131-136, 
Karalejič, M., Jakovljevič, S. (2001). Osnove košarke, Universitet u Beogradu.

Cassidy, T., Jones, R., Potrac, P. (2004). The social, cultural and pedagogical foundations of coaching practice. New York: Routledge;. Understanding sports coaching. Coysi, B., Power, F. (1983). Basketball-concepts and techniques. Allyn and Bacon. Boston.

Cushion, CJ., Armour, KM., Jones, RL. (2006). Locating the coaching process in practice: models "for" and "of" coaching. Phys Educ Sport Ped,11(1):83-99.

\section{Corresponding author:}

Mariana Borukova

National Sports Academy "Vassil Levski"

Department Basketball, volleyball, handball

21 Acad. Stefan Mladenov, Sofia, 1700

E-mail: marianaborukova@gmail.com 